\title{
BACKGROUND OF USING RENEWABLE ENERGY SOURCES IN ORDER TO ENSURE ENERGY EFFICIENCY OF UKRAINE
}

\begin{abstract}
In recent years an active growth of renewable energy production in the world has been observed. The peculiarity of our country is the presence of a large number of natural energy resources which put Ukraine among the electricity exporting countries, on the one hand, and the availability of virtually all types of renewable energy production (solar energy, hydropower (large and small), wind, etc.), on the other one. So we made an analysis of possibilities of an introduction the renewal energy from $1 \%$ of total energy production we have now to a bigger number and proposes the steps to achieve this goal. Given the statistic and existing situation in energy market, the resource base for renewable energy sources and local fuels is large and sufficient for a significant increase in the energy efficiency and the reliability of Ukraine's energy supply, and can be the basis for the transition to clean energy for the future.
\end{abstract}

Keywords: renewal energy, energy saving, energy efficiency, power station, bio fuel.

\section{INTRODUCTION}

The problem of energy efficiency and usage of renewable energy sources is one of the main problems being discussed in the world energy community. This issue has become a compulsory issue since 2001, and till then it is contained in the documents of the Energy Package developed by the Commission of the European Communities on the formation of the EU energy strategy, including the "Road card" in the field of renewable energy.

In recent years an active growth of renewable energy production in the world has been observed. For example, in Europe renewable energy accounted for $77 \%$ of all new EU power installations in 2015: $22.3 \mathrm{GW}$ of a total $29 \mathrm{GW}^{2}$. The EU has plans to increase the share of renewable energy in the energy balance to $20 \%$ by 2020 , which is primarily due to the desire to increase energy security since the EU countries are mainly energy importing countries.

The peculiarity of our country is the presence of a large number of natural energy resources which put Ukraine among the electricity exporting countries, on the one hand, and

\footnotetext{
${ }^{1}$ Nataliia Gerasymchuk PhD, Department of Economics, Faculty of Management, Rzeszow University of Technology, e-mail: n.gerasymchu@ @rz.edu.pl.

Dr Nataliia Gerasymchuk, adiunkt, Katedra Ekonomii, Wydział Zarządzania, Politechnika Rzeszowska, e-mail: n.gerasymchu@ prz.edu.pl.

2 Wind in power: 2015 European statistics. http://www.ewea.org/fileadmin/files/library/publications/ statistics/EWEA-Annual-Statistics-2015.pdf.
} 
the availability of virtually all types of renewable energy production (solar energy, hydropower (large and small), wind, etc.), on the other hand.

\section{MATERIAL AND METHODS}

Research presented in this paper is an element of a research project aimed at solving the problems of resource-saving in agro production complex of Ukraine. The research is concentrated on seeking and analyzing factors which make all branches of agriculture more resource efficient, thus decreasing the value of products and ensuring ecology friendly production due to the new technologies. Considering that agriculture in Ukraine covers $75 \%$ of its territory, the question of resource-efficient production became the question of national security. When it comes to enterprises that carry the examined resource-saving, and more particular, energy-saving, this paper is focused only on the analysis of background for using renewable energy sources in order to ensure energy efficiency of Ukraine. Research was conducted with the use of quantitative and qualitative methods. The subjects chosen for qualitative research included enterprises which use the cogeneration station on biogas, however due to scale of the study we made then as the example. Quantitative research used the statistical method of analysis. Research material was collected for the period from 2013 to 2016 .

\section{BACKGROUND OF USING RENEWABLE ENERGY SOURCES IN UKRAINE AND EUROPEAN UNION}

Here are the data on the use of renewable energy in Ukraine and other countries.

In terms of the use of renewable energy, Ukraine lags behind most countries in the world. The share of renewable energy in primary energy production in Ukraine in 2016 was $1 \%$ (without hydro power plants), and electricity generation, including small hydropower plants $-1.7 \%$. However, these indicators were achieved mainly due to the actions of individual managers and specialists ${ }^{3}$.

In Germany, over $11 \%$ of primary energy production is based on renewable energy, and more than $30 \%$ in the power generation sector ${ }^{4}$.

The intensive growth of renewable energy use, especially since the beginning of the $21 \mathrm{st}$ century, is typical for most developed and many developing countries. Thus, the share of electricity generated from non-traditional renewable energy sources in 2016 in the EU countries (in total production): in Denmark - $12.1 \%$, Finland $-13.1 \%$, Hungary $-4 \%$, Greece $2.8 \%$, Italy $-2.8 \%$, Spain $-2.8 \%$, Germany (in 2016) - $14.2 \%$, which amounted to 87.6 billion $\mathrm{kWh}$, including: small hydropower plants -20.7 billion KWh, wind power plant 39.5 , power plants on biomass and biogas -23.8 , solar batteries -3.5 , geothermal energy 0.1 . A similar situation develops for other types of renewable energy production ${ }^{5}$.

\footnotetext{
${ }^{3}$ Materials of press-conference "How will Ukraine benefit from the German experience in developing green energy?/ http://oilreview.kiev.ua/2016/02/15/v-mirovoj-energetike-dolzhny-proizojti-3revolyucii-ekspert/

${ }^{4}$ G. Geletucha, T. Zheleznaya, Status and prospects of development of bioenergy technologies in Ukraine, "Ecology of enterprise" 2015, No. 4,p. 32-41.

${ }^{5}$ Bioenergy will replace gas / http://zyma.in.ua/ru/print/175
} 
Renewable energy is a unique industry that incorporates the achievements of many sciences: from meteorology to metal science. If we consider wind power as an example, in the leading countries local firms (many of which are medium-sized businesses) occupy $50-70 \%$ of the national market. In the process of developing national wind power in Spain, more than 60,000 new jobs were created. In Germany, the wind energy sector had a turnover of more than 7 billion euros in 2014, 12 manufacturing companies, 653 wind power plants serving a total installed capacity of over 19 thousand MW, with a total workforce of 8,600 people ${ }^{6}$.

According to the energy balance of Ukraine for 2016, prepared by State Statistic Service of Ukraine, the share of renewable energy sources in gross final energy consumption is $1 \%$, including biomass $-0.63 \%$, which is $63 \%$ of all renewable energy sources. Compared to 2015 , there is a noticeable increase in the contribution of biomass to the total supply of primary energy - by $23 \%$.

Table 1. The place of renewable energy sources and biomass in the energy balance of Ukraine

\begin{tabular}{|l|c|c|c|c|}
\hline \multicolumn{1}{|c|}{ Indicators } & $\mathbf{2 0 1 3}$ & $\mathbf{2 0 1 4}$ & $\mathbf{2 0 1 5}$ & $\mathbf{2 0 1 6}$ \\
\hline $\begin{array}{l}\text { Share of renewable energy in the total supply of primary } \\
\text { energy, }\end{array}$ & 1,98 & 2,01 & 1,165 & 0,94 \\
\hline $\begin{array}{l}\text { Share of renewable energy in gross final energy consumption } \\
* \%\end{array}$ & 3,45 & 3,45 & 3,45 & 3,45 \\
\hline Biofuel in the total supply of primary energy, million tons & 1,56 & 1,52 & 1,088 & 0,972 \\
\hline Biofuel in the total supply of primary energy,\% & 1,23 & 1,23 & 0,625 & 0,475 \\
\hline Biofuel in gross final energy consumption* million tons & 1,45 & 1,47 & 1,19 & 1,125 \\
\hline Biofuel in gross final energy consumption*\% & 1,79 & 1,89 & 1,293 & 1,157 \\
\hline $\begin{array}{l}\text { The share of biofuel among renewable energy sources in gross } \\
\text { final energy consumption *\% }\end{array}$ & 67 & 68 & 63,2 & 62,8 \\
\hline
\end{tabular}

* - Calculation of authors according to the energy balance of Ukraine for 2013-2016, prepared by State Statistic Service of Ukraine.

For 2017-2018, predicted even greater growth due to the urgent need to replace biomass with alternative fuels and the introduction of activities that contribute to this process.

\section{ANALYSIS OF POTENTIAL RENEWABLE ENERGY SOURCES IN ORDER TO ENSURE ENERGY EFFICIENCY OF UKRAINE}

Taking the rather big share of biogas power station, lets analyze this type of renewal energy source and its potential in Ukraine. According to the head of Bioenergy association of Ukraine Georgy Geletucha, installed capacity of biogas power generation facilities in accordance with the concept of electricity production from biomass in Ukraine is quite powerful, which is shown in Table 2.

\footnotetext{
${ }^{6}$ V.V. Kaplun, V.H. Shcherbak, Multifactor analysis..., p. 349-359.
} 
Table 2. Installed power capacity of objects of electricity generation on biomass according to conception of biomass energy production*

\begin{tabular}{|l|c|c|c|c|c|}
\hline \multicolumn{1}{|c|}{ Indicators } & \multirow{2}{*}{$\mathbf{2 0 1 0}$} & \multicolumn{4}{c|}{ Forecast } \\
\cline { 3 - 6 } & & $\mathbf{2 0 1 5}$ & $\mathbf{2 0 2 0}$ & $\mathbf{2 0 2 5}$ & $\mathbf{2 0 3 0}$ \\
\hline Installed capacity of electric plant on biomass, MW & 4 & 112 & 533 & 1181 & 2133 \\
\hline Power structure, MW: & & & & & \\
\hline $\begin{array}{l}\text { Reconstructed coal power plants (co-fired biomass } \\
\text { with coal) }\end{array}$ & 0.0 & 0.0 & 91 & 230 & 389 \\
\hline $\begin{array}{l}\text { Share of electricity production from biomass in } \\
\text { coal blocks (no more than 300 MWe) }\end{array}$ & $0 \%$ & $0 \%$ & $1 \%$ & $2.5 \%$ & $4.2 \%$ \\
\hline Power plant on biomass & 0,0 & 31 & 54 & 87 & 110 \\
\hline Cogeneration station on biomass & 4,1 & 51 & 216 & 497 & 890 \\
\hline $\begin{array}{l}\text { Power plant / Cogeneration station at the municipal } \\
\text { solid waste }\end{array}$ & 0.0 & 0.0 & 43 & 118 & 257 \\
\hline $\begin{array}{l}\text { Cogeneration plants on biogas from municipal } \\
\text { solid waste poligons }\end{array}$ & 0.2 & 10 & 27 & 32 & 40 \\
\hline Cogeneration plants on biogas & 0.0 & 21 & 102 & 217 & 446 \\
\hline
\end{tabular}

* Source: G. Geletucha, T. Zheleznaya, Status and prospects of development of bioenergy technologies in Ukraine, 2015.

In Ukraine there are now working 4 thousand modern solid fuel fired and biomass boiler, 100 boilers on straw and 70 boilers on the sunflower husks. There are several thermal power plants on solid biomass: 1 - wood in the heating system, 3 - on the sunflower husks at the fat and oil industry. In addition, the population uses thousands of furnaces and household boilers on wood and wood pellets ${ }^{7}$.

To ensure the necessary volume of fuel for all bioenergy plants planned for introduction, it is necessary to widely involve waste from agro-industrial complex and energy crops in the country's fuel and energy balance.

In addition, it is necessary to increase the volume of felling from the current 55-60\% of the annual growth of wood in Ukraine to $85-90 \%$ of the annual growth, as practiced in the EU countries ${ }^{8}$.

In 2014, Ukraine adopted a number of government resolutions aimed at stimulating the substitution of natural gas for alternative types of energy and for harmonizing the renewal energy production sector with the European one.

In particular, the plan adopted by the government in autumn 2014 for short- and medium-term measures to reduce the volume of natural gas consumption for the period until 2017 provides for a number of important measures.

1. Granting the status of priority for investment projects for transferring consumers from natural gas to other types of fuel and energy.

2. Improving the methodology for calculating the tariff for the production of thermal energy from fuels other than natural gas: the application of the accelerated deprecia-

\footnotetext{
${ }^{7}$ State statistic Service of Ukraine - www.ukrstat.gov.ua.

8 V.V. Kaplun, V.H. Shcherbak, Multifactor analysis of university buildings' energy efficiency,

“Actual problems of economics" 2016, №12 (186), p. 349-359.
} 
tion of equipment, the establishment of a maximum level of the regulatory revenue rate for such projects is not lower than $25 \%$.

3. Simplification of the procedure for transferring to concession, renting and lifting of the ban on privatization of heat power facilities of communal ownership.

4. The implementation of the term "biomass" in national legislation in accordance with EU directives.

5. Development of technical conditions for the admission of bio methane to the gas transport system of Ukraine, a mechanism for stimulating its production and consumption.

6. Amendments to the Energy Strategy of Ukraine until 2030 in terms of reducing natural gas consumption, increasing the use of renewable energy sources and alternative fuels.

7. Simplification of the procedure of land allocation for facilities for the production of heat and electricity using alternative fuels.

8. Reduction of the number of permits for the implementation of gas substitution projects and the timing of their issuance.

9. Amendments to the laws "On Heat Supply" and "On Natural Monopolies" on the transition to alternative fuels and to the stimulating regulation of relevant economic entities.

In addition, the government introduced additional mechanisms to stimulate the replacement of natural gas in the heat supply of the population and budget organizations, which includes indicators of the effectiveness of measures of energy conservation.

\section{ECONOMIC JUSTIFICATION OF RENEWABLE ENERGY PRODUCTION}

Indicators of the effectiveness of measures to ensure energy conservation, on the one hand, are part of the system of indicators of the effectiveness of financial, production, innovation activities of the enterprise, as well as the effectiveness of personnel management and resource provision processes and are calculated using data on the results of these activities. On the other hand, the implementation of energy saving measures influences the assessment of the performance of the enterprise as a whole (economic, production, investment indicators, etc.), the effectiveness of which is characterized by relevant indicators 9 .

To assess and analyze the company's energy efficiency in dynamics, the following economic data are required, as determined by the financial system ${ }^{10}$ :

1. The value of the added economic value (value) created at the enterprise for several periods):

$$
\text { AEV }=\text { EBIT }- \text { T-DCC }
$$

where: AEV - added economic value, UAH; EBIT - operating profit; $\mathrm{T}$ - the amount of taxes paid; DCC - normal capital expenditure (product of market valuation of capital (own and borrowed) and its weighted average cost);

2. The cost of production for several periods;

9 N.A. Gerasymchuk, Development of resource saving strategy in economic activity of agricultural enterprises / N.A. Gerasymchuk // Modern Management Review. - № 1, 2013.- P. 21-28.

${ }_{10}$ N.A. Gerasymchuk, Entrepreneurial mechanism of resource-saving development in agro productional complex, Kyiv 2016, 464 p. 
3. Net profit of the enterprise in dynamics;

4. Structure of the cost price of the products with an indication of the share of energy costs and its dynamics.

When assessing the effectiveness of investments in energy conservation, the following data characterizing the investment activity of the enterprise:

- the total number of investment projects implemented by the enterprise during the analyzed period and the share of projects related to energy saving and energy efficiency improvement;

- the total amount of investments made by the enterprise with an indication of its share in the volume of investments in energy saving;

- total net discounted income received by the enterprise from all investment projects being implemented, incl. from projects related to energy saving.

Energy saving also affects production indicators such as energy intensity of products, energy efficiency of production activities, in some cases - output of products.

Indicators of efficiency of investments in energy conservation are part of the overall system of indicators for assessing the effectiveness of all investments of the enterprise. A certain part of the investment projects of the enterprise is an innovative project related to energy saving, therefore it is appropriate to allocate a group of indicators for assessing the effectiveness of innovations

In the system of indicators for assessing energy efficiency, it is necessary to identify indicators related to the qualification of personnel. This group of indicators is mainly represented by indicators of the upgrading of engineering and working personnel in connection with its training in conducting an internal energy audit at the enterprise.

Energy saving also affects the efficiency of providing the enterprise with resources, in these case energy resources. A more rational organization of the company's interaction with energy suppliers or energy saving in the production determines the increase in the effectiveness of these activities.

We can divide the main mechanisms for implementing the energy strategy into such sectors:

- formation of a rational market environment;

- government support of energy saving initiatives of enterprises and citizens;

- state technical regulation.

\section{CONCLUSIONS}

Based on above mentioned sectors we are proposing the following elements of future mechanism of renewal energy development in Ukraine:

1. Developing the biomass market. Special attention should be paid to the use of the economic potential of biomass (about 23 million tons of equivalent fuel) as the most common and accessible type of resource, which also allows for multiple forms of use, simple combustion (wood, logging residues and wood processing, crop waste); Production of biogas with its further use in boilers and internal combustion engines (livestock and poultry waste, urban sewage sludge), gas generation (waste from plant growing and wood processing, wood) and liquid fuel obtained either from specially grown crops (rapeseed oil) or through processing of plant and wood products. 
2. Geothermal energy (economic potential of 14 million tons of equivalent fuel) for the purposes of heat supply in the Carpathian and South regions should be applied substantially. Part of the geothermal energy (ground heat and mineral water with a temperature below $50^{\circ} \mathrm{C}$ ), which can be used for heat supply with heat pumps, has entered the category of "low-potential heat use".

3. Most of the regions of Ukraine can significantly improve the reliability of energy supply, especially remote settlements due to the construction of small hydropower plants. The economic potential of this resource is 7 million tons of standard fuel per year and there is a good production base for its implementation.

4. Good resource of renewal energy is low-potential heat, the magnitude of which is significant, more than 5 million tons of standard fuel per year. Particular attention should be paid to enterprises, in systems of which various cooling devices are used by technology. Heat pumps can be used instead of water coolers. Their use in these systems is most effective, since the cooled water has a temperature of $40^{\circ} \mathrm{C}$ and higher.

5. The economic potential of wind energy in Ukraine is not so great, only 1 million tons of standard fuel per year, but it tends to increase, including due to the widespread growing energy deficit generated by traditional power plants. Unconditional economic efficiency of wind farms operating in power systems takes place at an average annual wind speed of $7 \mathrm{~m} / \mathrm{s}$ and higher. The most economically viable area of application of wind turbines at present is autonomous power supply systems based on diesel stations. Wind-diesel power stations can save up to 30 percent or more of expensive imported diesel fuel.

6. Solar energy occupies the most modest place in terms of economic potential (only 3 million tons of standard fuel per year) and one of the most significant in terms of technical potential (about 10 billion tons of standard fuel per year). But from this economic potential one ten-thousandth part is used. And if the introduction of photovoltaic systems is hampered by their high cost and loss of the most powerful in Europe solar power station in Autonomy Republic of Crimea.

\section{SUMMARY}

Given the statistic and existing situation in energy market, the resource base for renewable energy sources and local fuels is large and sufficient for a significant increase in the energy efficiency and the reliability of Ukraine's energy supply, and can be the basis for the transition to clean energy for the future.

\section{REFERENCES}

1. Arefieva O.V., Managing of entrepreneurship formation, O.V. Arefieva, N.A.Gerasymchuk, Kyiv 2006.

2. Geletucha G., Zheleznaya T., Status and prospects of development of bioenergy technologies in Ukraine. Ecology of enterprise 2015.

3. Gerasymchuk A., Forms and specifics of resource provision of economic subjects in agriculture / A. Gerasymchuk, N. Gerasymchuk // Humanities and social sciences - № 2, 2014.

4. Gerasymchuk N. A. Development of resource saving strategy in economic activity of agricultural enterprises / N. A. Gerasymchuk // Modern Management Review. - № 1, 2013. 
5. Gerasymchuk N.A., Theoretical approach to examination of economic security of agricultural enterprises in Ukraine/ N.A. Gerasymchuk // Current state and perspectives of enterprises' development in conditions of international economic activity [monograph] - Matej Bel University, Banska Bystrica, Slovakia 2013.

6. Gerasymchuk N.A., Entrepreneurial mechanism of resource-saving development in agro productional complex, Kyiv 2016.

7. Malik M., Motivation of manager's responsibility in business entities of rural tourism / M.Malik, L.Zaburanna, N.Gerasymchuk // Journal of Financial Management and Accounting - 2016. - № 4 (1).

8. Viktor V. Kaplun V.V., Shcherbak V.H, Multifactor analysis of university buildings' energy efficiency, "Actual problems of economics” 2016, №12 (186).

9. Zaburanna L., Optimization of agriculture production on the basis of resource saving strategy /L. Zaburanna, N. Gerasymchuk // Humanities and Social Sciences. - 2014, No. 21.

\section{INTERNET SOURCES}

1. Bioenergy will replace gas / http://zyma.in.ua/ru/print/175

2. Materials of press-conference "How will Ukraine benefit from the German experience in developing green energy?/ http://oilreview.kiev.ua/2016/02/15/v-mirovoj-energetike-dolzhnyproizojti-3-revolyucii-ekspert/

3. State statistic Service of Ukraine - www.ukrstat.gov.ua

4. Wind in power: 2015 European statistics, http://www.ewea.org/fileadmin/files/library/publications/statistics/EWEA-Annual-Statistics-2015.pdf

\section{ZASADY WYKORZYSTYWANIA ODNAWIALNYCH ŹRÓDEŁ ENERGII DLA ZAPEWNIENIA ENERGETYCZNEGO BEZPIECZEŃSTWA UKRAINY}

W ostatnich latach obserwuje się aktywny wzrost produkcji energii odnawialnej na świecie. Osobliwością Ukrainy jest obecność dużej ilości naturalnych zasobów energii, które zaliczają ją do krajów eksportujących energię elektryczną. Kraj ten zajmuje się również produkcją energii odnawialnej (energia słoneczna, energia wodna, wiatrowa itp.). W artykule dokonano analizy możliwości wprowadzenia energii odnawialnej pochodzącej z 1\% całkowitej produkcji energii, którą mamy obecnie oraz zaproponowano rozwiązania do osiągnięcia tego celu. Biorąc pod uwagę statystykę i obecną sytuację na rynku energii, baza zasobów dla odnawialnych źródeł energii i lokalnych paliw jest duża i wystarczająca dla znaczącego wzrostu efektywności energetycznej i niezawodności dostaw energii na Ukrainie i może być podstawą do przejścia na czystą energię na przyszłość.

Słowa kluczowe: energia odnawialna, oszczędność energii, efektywność energetyczna, elektrownia, biopaliwa.

DOI: $10.7862 /$ rz.2018.hss.68

Tekst ztożono do redakcji: marzec $2017 \mathrm{r}$.

Tekst przyjęto do druku: grudzień 2018 r. 